\title{
The effect of E-learning on education process enhancement \& in-house customers' satisfaction (An experimental design)
}

\author{
Amani Younes Merzeban \\ Arab Academy for Science, Technology \& Maritime Transport, Egypt \\ Ismail M. El-Sayed \\ Nile University, Egypt \\ Mohamed A. Ragheb \\ Arab Academy for Science, Technology \& Maritime Transport, Egypt
}

\author{
Keywords \\ e-learning, HE sectors, Covid-19, education process enhancement, Egypt
}

\begin{abstract}
At present, Higher education sector in Egypt plays an important role. The exponential change in technology initiates improving its services. As a result of the increased pressure to improve competitiveness, and due to COVID19 circumstances, academic institutions are motivated to adopt a system perspective, elevating strategies towards achieving E-learning. This research is mainly targeting exploring practices of E-learning in higher education, its influence on enhancing the education process and in-house customers' satisfaction (students). There's a dissimilarity between Elearning teaching and the traditional teaching, there are many debates. Creating effective E-learning environment has become a top priority for higher academic institutions.

The parameters of the E-learning system effectiveness are not revealed. The main objective of this research is to find out whether the online teaching method compared to the traditional teaching method, in different colleges of the Arab Academy for Science, Technology and Maritime Transport (AASTMT); will achieve a higher quality level than that created using the traditional education approach in specific.

The research aims at exploring students' perceptions towards E-Learning teaching method $\mathcal{E}$ traditional teaching method concerning learning environment satisfaction, quality of achievements and performance. The research approaches adopted in this study includes executing an experimental study using a quasi-experiment design to direct the Arab Academy for Science, Technology $\mathcal{E}$ Maritime transport (AASTMT) to different knowledge bases in instruction technology. Moreover, the findings from this research would provide evidence and add to the body of knowledge in higher education. The methodology of the research is seeking to apply E-learning to manage development and improve performance, as a starting point to assess the effect of applying E-learning on enhancing the education process.

This research is the first in higher education in Egypt to hold a comparison between teaching methods and study the effect of this combination of dimensions together and analyze the E-Learning teaching method effect on enhancing education and improving quality. Finally, the research will elaborate the problems faced to improve the E-Learning teaching method as a prerequisite for higher education since the beginning of COVID19 pandemic.
\end{abstract}

\section{Introduction}

Enhancing the learning process by applying modern technology methods, is an attempt to seek attractive growth opportunities and to enrich experience, so as to develop systems that are adaptable to change and to review the framework for organizational learning and the transformational perspective, in addition to examine a formula for a learning organization.

Measuring students' quality of achievements, in house customers' satisfaction (students) and performance could be used to ascertain the effectiveness of a learning format since students are considered the in-house customers in this instance (Macgregor, G; Turner, J, 2009). In developing the technology of instruction and enhancing it with new communication tools and learning techniques to enrich experience, a learning environment that supports the goals and objectives of the learner has to be 
created, while taking into consideration the possibilities and limitations of appropriate technology to deliver the instruction.

\section{Research problem}

The main objective of this research is to investigate if E-learning teaching method compared to the traditional teaching method at different colleges at The Arab Academy for Science, Technology \& Maritime Transport (AASTMT) would overcome the gap to realize a higher perceived quality level than that created by using the traditional education approach in specific.

Accordingly, the research is dealing with E-learning as an alternative to traditional learning and taking into consideration the different forms of electronic technologies in the educational process that Elearning entails. The methodology of the research is seeking to apply E-learning to manage development and improve performance, as a starting point to assess the effect of E-learning on enhancing the educational process. The research aims at exploring students' perceptions towards E-Learning teaching method \& traditional teaching method concerning in house customers' satisfaction, quality of achievements, and performance.

\section{Literature review}

Several studies discussed the effectiveness of E-learning education by putting a frame for successful measures to evaluate E-Learning in universities (Macgregor; Turner 2009; Tseng; Lin 2011; 2015; Bali \& $\mathrm{Liu}$, 2018). Exploring the E-Learning emphasis is needed for university improvement over its present place (Selim, 2007; Hassanzadeh et al. 2012; Al Sabawy et al. 2011; Al Sabawy \& Soar, 2013).

More understanding is needed on how students perceive online learning so as to apply those approaches effectively in order to enhance the learning process (Kouhang \& Durante, 2003).

The study of Attia et al. (2016) notified a lack of practical studies on the evaluation of learning management system (LMS) in higher education institutions. Studies didn't show how different criteria effect the LMS. Therefore, they proposed an evaluation criteria model that overcome the studies \& research limitations to discover new relations among different dimensions. Moreover, they highlighted criteria with higher influence on LMS, and shed light on the effect of technology use on lecturers and students.

Macgregor; Turner (2009); Nortvig, et al. (2018). Studies concluded that evaluating E-Learning systems tackles two main problems: firstly, the main factors in measuring the success of E-learning systems, and secondly, the validity and reliability of the model of evaluation of E-learning.

Lot of studies aimed at determining whether E-Learning is better than traditional learning in regard to learning outcomes and students' satisfaction.

The formats that lead to the best results in higher education institutions are the targets in comparative studies (Zare, et al. 2015).

The evaluation of E-Learning in higher education totally depends on assessing the criteria that contribute to enhancing the education process (Jafar Jalali et al. 2018; Lara et al. 2014).

There are three factors that directly affect the quality of E-learning systems: dimensions, constructs, and indicators. Raspopovic (2014), DeLone \& McLean (2003), all suggest that comprehensive reviews, as well as monitoring, of pre-existing E-learning systems are a must to determine the efficiency of E-learning in terms of user's satisfaction, academic achievements, service quality and performance. The hypotheses of the research are strongly supported by the literature. It was proven by the literature that the effect of ELearning has a distinguished effect in analyzing the main dimensions of the study; the in-house customers' satisfaction; the quality of achievements and the performance; that affect the education process (Loh. et al. 2016; Macgregor; Turner 2009; Hadullo et.al. 2017; Kaplan; Owings; 2015; Aly. et al. 2018; Vivek. et al. 2016.

\section{In House customers' satisfaction}

Attia et al. (2016) introduced in their research a multidimensional view of the most critical criteria that suits the Egyptian universities. Their criteria of evaluation are composed of six dimensions: Effectiveness of content, Communication, technology, lecturers and students' dimensions, system, and service quality. The most important relations among the criteria of their studies showed positive relationships between students' attitude toward technology and their level of satisfaction, moreover 
positive relationships are among students' satisfaction and the quality of services and lecturers' responsiveness.

Tratnik (2017) investigated students' satisfaction of learners of English as a foreign language and found out that students that studied with the traditional method were more satisfied than their peers that studied with E-Learning method. Many researchers notified that students tend to be more satisfied with face-to-face interactions (Bali \& Liu, 2018). The research of Kemp \& Grieve (2014) found results showing that Psycology students at an Australian University were more satisfied with traditional learning method than the E-Learning method although their academic performance levels were the same.

As user satisfaction is a means of measuring E-learning success, the attention given to the user satisfaction approach by researchers led to light being shed on it in terms of E-learning systems. According to Sun et al. (2008), there are 6 dimensions that drive E-learning success; learner, instructor, course, technology, design, and environmental.

Many researchers argued that students' have greater satisfaction in regard to the face-to-face interactions (Bali \& Liu, 2018). Their study has a limitation that the students that participated with their perceptions was from one field and one gender.

Although traditional teaching method perceived higher students' satisfaction than E-Learning teaching method, more students' numbers registered in online Learning and there was no significant difference among students registered in both learning methods regarding their learning levels (Cuthrell \& Lyon; 2007 in Bali, S \& Liu, M 2018).

Accordingly, the first hypothesis would be stated

H1: The mean effect of E-Learning on in house customers'(students) satisfaction would be higher than that of the traditional learning.

\section{Quality of achievements}

A demand-driven learning model was proposed by MacDonald et al. in 2001. Five essential dimensions to increase E-learning quality in higher education comprises model; structure, content, delivery, system, and outcome.

In the studies of Bernard et al. (2014); and Gonzalez et al (2016, comparisons revealed that Elearning students had better and higher achievements than traditional students. Bernard et al. (2014) concluded that the use of technology seems to lead to a very low students achievements improvements in lack of students' interactions. Researchers recommended the necessity of lecturer's availability for students online or in person to prevent isolation feelings (Hunt, 2015). The first three dimensions of assessment in the DeLone and McLean (2003) model are system quality, information quality, and service quality. These three dimensions represent quality assessment for system design. In the context of ELearning, system quality evaluates the characteristics and effectiveness of the used platform such as flexibility, stability, reliability, security, responsiveness, and user-friendliness.

King, E; Boyatt, R; (2014) recommended in their study continuous development of organization infrastucture \& culture for the implementation and improvement of E-Learning is needed. Moreover, identifying the critical factors for implementing E-Learning successfully for guiding the organization change. Giving considerations for developing participants' experiences regarding their perspectives and the resistance to change in some cases. Tarus (2015) stated that institutional factors such as the availability of technology, and proper maintenance affect the quality of E-learning. Lastly, overall performance in terms of service quality is also a contributing factor (DeLone \&McLean, 2003; Raspopovic, 2014).

Accordingly, the second hypothesis would be stated

H2: The mean effect of E-Learning on quality of achievements would be higher than that of the traditional learning.

\section{Performance}

Wright's (2014) model for evaluating the performance quality of E-learning systems in higher education in developing countries suggests that there are three main factors in the assessment of Elearning. These factors are Continuous Assessment Tests (CATs), assignments, and semester exams.

E-learning aspects such as socio-demographic characteristics, hours spent on-line, and prior computer skills cast a more positive light on how such factors affect the e-learning experience and overall performance of students (Al Jawarneh, 2020). 
Mwalumbwe, I; Mtebei, J; (2017) highlighted that some studies have shown positive significance between LMS usage (no of downloads, no of visits, no of LMS tools, messages, and content pages visited) and students' performance. The analysis of LMS usage could explain the variation in final grades which predict the learning achievements.

Debattista, M; (2018) noticed that new developments in online learning evaluations increased empirical evidence and have effective roles in enhancing the education process. The study recommended for future research that give weights to the evaluated dimensions and analyze the outcomes of the learning process.

Elfaki, N; et.al. (2019) elaborated conflicting findings from the literature that ranged students' performance from positive, negative and no significant differences in students' performance. Their study findings had significant results for E-Learning experiment group performance for a single course using ELearning for the first-time which may could have biased the study findings with lack of experience and varying students' expectations.

The contradictions among opinions towards traditional learning and E-learning highlighted a critical part of the research problem. Some opinions necessitate the important role of E-learning for skills development. While others identify the absence of human interaction which exists in traditional learning as a source of major concern on online learning. (Loh et al., 2016; Fischer et al., 2015). There is lack of research about how students perceive E-learning and how it affects their learning experience. Another area that lacks research is the different outcomes of traditional learning methods versus E-learning. Thus, evidence is needed to demonstrate how both teaching methods of learning could help enhance the learning process by more understanding of how students perceive and react to the E-Learning dimensions (Bali \& Liu, 2018).

Accordingly, the third hypothesis would be stated

H3: The mean effect of E-Learning on performance would be higher than that of the traditional learning.

Hypothesis and models are derived from the literature of the previous studies. Therefore, the current research will demonstrate the evidence needed from the analysis of the quasi-experimentation results.

\section{Study model}

Based on the literature review, the following figure represents the suggested model of the study.

Figure (1): The suggested Model of The Study

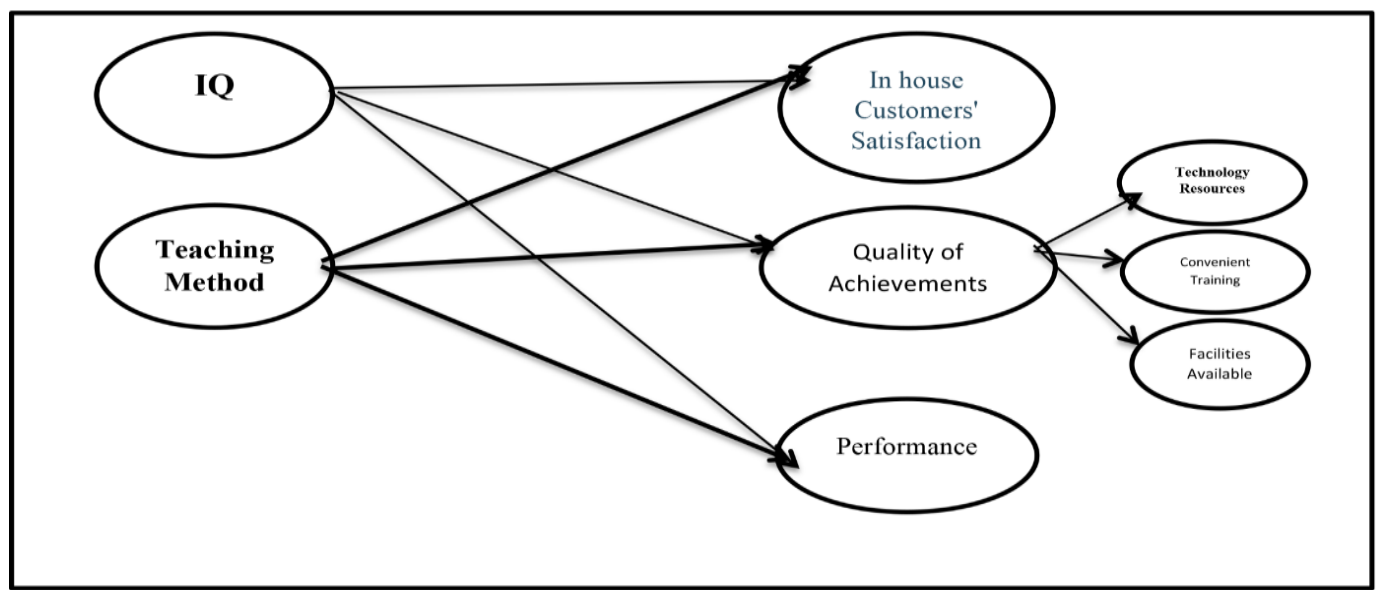

\section{Research methodology}

Research Design: to examine the research models, the research adopted a quasi-experiment to test the research hypotheses or to examine the suggested model. Its basic design is posttest and control group design; the posttest design measures the effect of the independent variable on the dependent variables (post treatment). The experiment consisted of two groups, a control group, and an experimental group. The control group is involved in the traditional learning and teaching process and the experimental group uses the E-learning teaching method. 
In this research, quantitative methods have been used to collect data from students based on the proposed evaluation criteria. A survey questionnaire to measure students' perceptions in regard to the learning environment satisfaction and the quality of achievements was used. The aim is to investigate how differences of in-house customers (students) perceptions would affect the education process.

Furthermore, the research aims at comparing the E-learning teaching method to the traditional teaching method at different colleges at The Arab Academy for Science, Technology \& Maritime Transport (AASTMT); that may realize a higher perceived in-house customers' satisfaction, quality of achievements and performance, than that created by using the traditional education approach in specific.

Measurements: a structured questionnaire to collect students' perceptions; and fulfill the research variables were used among students in different colleges (College of Engineering \& Technology, College of Management \& Technology, College of Pharmacy). Data collected was statistically analyzed using the statistical package for social sciences (SPSS 25) and (AMOS 22), a statistical software used for Structural Equation modeling, path analysis, and confirmatory factor analysis.

Study Sample: A purposive sample from the registered students at the Arab Academy for Science and Technology and maritime Transport (AASTMT) at theoretical and practical colleges. Performance will be analyzed from students' exams, results, and GPA's. Students' perceptions questionnaires to collect data from the sample would be used to collect perceptions about the quality of achievements and students' satisfaction. The students' perceptions questionnaire focused on the evaluation of the teaching methods and have been applied to 515 undergraduate students. The sample was selected from the students learning with the traditional teaching method and their peers learning with the E-Learning teaching method to collect their perceptions.

\begin{tabular}{|c|c|c|c|}
\hline Variable & $\begin{array}{l}\text { Conceptual } \\
\text { definition }\end{array}$ & $\begin{array}{l}\text { Operation } \\
\text { definition }\end{array}$ & Scale \\
\hline Performance & $\begin{array}{l}\text { An action or type of } \\
\text { behavior that involves } \\
\text { lot of attention to } \\
\text { details or to small } \\
\text { matters. }\end{array}$ & $\begin{array}{l}\text {-Students' progression } \\
\text {-Learning Efficiency }\end{array}$ & $\begin{array}{l}-7^{\text {th }} \text { exam } \\
-12^{\text {th }} \text { exam } \\
\text {-Quizzes } \\
\text { assignments of } \\
\text { end of tracks or } \\
\text { chapters } \\
\text { - final exam } \\
\text { - Learning } \\
\text { outcomes GPA } \\
\text { (Good student - } \\
\text { Fair student - } \\
\text { average student). } \\
\text {-Student } \\
\text { Reporting and } \\
\text { average grades. } \\
\text { - Current GPA }\end{array}$ \\
\hline $\begin{array}{l}\text { Quality of } \\
\text { achievement }\end{array}$ & $\begin{array}{l}\text { Teaching quality includes } \\
\text { creating a positive } \\
\text { learning climate, } \\
\text { selecting appropriate } \\
\text { instructional goals and } \\
\text { assessments, using the } \\
\text { curriculum effectively, } \\
\text { and employing varied } \\
\text { instructional technology } \\
\text { facilities that help all } \\
\text { students learn at higher } \\
\text { levels. }\end{array}$ & $\begin{array}{l}\text {-Technology \& } \\
\text { Recourses } \\
\text {-Facilities Available } \\
\text {-Convenient Training }\end{array}$ & $\begin{array}{l}\text { Quality of } \\
\text { achievement will } \\
\text { be measured } \\
\text { through the } \\
\text { Students' } \\
\text { perceptions about } \\
\text { learning method } \\
\text { questionnaire to } \\
\text { assess quality of } \\
\text { achievement in } \\
\text { education } \\
\text { activities (Isik, A } \\
\text { 2009). }\end{array}$ \\
\hline $\begin{array}{l}\text { In house } \\
\text { customers' } \\
\text { satisfaction }\end{array}$ & $\begin{array}{l}\text { It is a measure of how } \\
\text { the products and } \\
\text { services meet or } \\
\text { surpass customers' } \\
\text { expectations. }\end{array}$ & $\begin{array}{lr}\text {-Satisfaction of } \\
\text { Learning environment }\end{array}$ & $\begin{array}{l}\text { In house } \\
\text { customer' } \\
\text { satisfaction will } \\
\text { be measured } \\
\text { through the } \\
\text { Students' } \\
\text { perceptions about } \\
\text { learning method } \\
\text { questionnaire to } \\
\text { assess the } \\
\text { satisfaction of the } \\
\text { learning } \\
\text { environment } \\
\text { (Isik, A 2oO9). }\end{array}$ \\
\hline
\end{tabular}

Table (1): Conceptual and Operational Definitions of the tested study variables

Table (1) presents the conceptual and operational definitions of the tested variables of the study. The questionnaire about the quality of achievements consisted of 31 questions while that about the learning environment students' satisfaction consisted of 10 questions. Questions scales ranged from (1) Strongly disagree, disagree (2), Neutral (3), Agree (4), and (5) Strongly agree. 


\section{Data analysis \& results}

Data were collected from a sample of a total of 515 students and after data cleaning of the missing data the sample resulted in 453 students. 237 students of whom had undergone their lectures according to the traditional teaching method which represent $52 \%$ of the sample. In addition to 216 students according to the E-learning teaching method, response rate was approximately $87.96 \%$.

The questionnaire was distributed to 515 students in the mentioned colleges at AASTMT. After revision of students' perceptions and IQ tests and data cleaning, total responses of 453 out of 515 were found with no missing values for analysis. The response rate was $87.96 \%$. Students were subjected to a 41 question questionnaire to measure Quality of achievements \& Customers' satisfaction through the students' perceptions questionnaire used to collect data for the study. Analysis of the questionnaire revealed that students did not answer questions randomly. No ambiguity or lack of understanding were shown. The data regarding the performance ( $3^{\text {rd }}$ dependent variable) that reveals the progression and efficiency of students was collected from various tests ( 7 th week exams, $12^{\text {th }}$ week exams, quizzes, final exam), grading, GPA, for determining each student's level of performance.

\section{Measurement model fit}

Confirmatory factor analysis (CFA) (Hair et.al., (2010), standardized factor loadings, Goodness of fit index (GFI), Root mean square error of approximation (RMSEA) were used for the measurement of the model fit.

Table (2): Measurement Model Fit Summary

\begin{tabular}{|c|c|c|c|}
\hline \multicolumn{4}{|c|}{ Measurement Model Fit Summary } \\
\hline Measurement & Value & optimal range & references \\
\hline $\mathrm{CMIN/DF}$ & 1.657 & $\begin{array}{l}\text { Relative Chi-Square } \\
\text { ratio of approximately five or less, } \\
\text { ratios in the range of } 2 \text { to } 1 \text { or } 3 \text { to } 1 \text { are } \\
\text { indicative of an acceptable fit between } \\
\text { the hypothetical model and the sample data }\end{array}$ & $\begin{array}{l}\text { Wheaton et al. (1977) } \\
\text { Carmines and McIver, 1981, } \\
\text { page } 80\end{array}$ \\
\hline GFI & 0.887 & $\begin{array}{l}\text { Goodness of Fit Index } \\
\text { GFI is less than or equal to } 1 . \\
\text { A value of } 1 \text { indicates a perfect fit }\end{array}$ & Tanaka and Huba (1985) \\
\hline CFI & 0.951 & $\begin{array}{l}\text { Comparative fit index } \\
\text { CFI values close to } 1 \text { indicate a very good fit }\end{array}$ & McDonald and Marsh (1990) \\
\hline RMSEA & 0.038 & $\begin{array}{l}\text { Root Mean Square Error of } \\
\text { Approximation } \\
\text { exact fit with the RMSEA }=0.0 \\
\text { about } 0.05 \text { or less would indicate a close fit } \\
\text { of the model in relation to the degrees of } \\
\text { freedom. }\end{array}$ & Tanaka and Huba (1985) \\
\hline
\end{tabular}

Table (2) shows the overall quality standards for the Measurement Model, and it is considered as the overall quality measurement for the three variables of the study.

\section{Hypothesis tests}

In order to test the research hypotheses and examine the study model two types of analysis were used. First, research hypotheses were tested using multiple analysis of covariance (MANCOVA). Since IQ test was used as a covariate in the analysis. This test was done using the (SPSS 25). Second, the fit of the model was tested using the structure equation model (SEM). This analysis was performed using (AMOS 22).

The results of the first analysis; the hypotheses tests are shown in table (3) 
Table (3): Parameter Estimates (MANCOVA)

\begin{tabular}{|c|c|c|c|c|c|}
\hline \multicolumn{6}{|l|}{ Parameter Estimates } \\
\hline Dependent Variable & Parameter & B & $\begin{array}{l}\text { Std. } \\
\text { Error }\end{array}$ & $\mathbf{t}$ & Sig.* \\
\hline \multirow{4}{*}{$\begin{array}{l}\text { Customers' } \\
\text { satisfaction }\end{array}$} & Intercept & 0.36 & 0.14 & 2.567 & 0.011 \\
\hline & $\begin{array}{l}\text { [Teaching Method }= \\
\text { Traditional] }\end{array}$ & $-.738-$ & 0.088 & $-8.427-$ & 0.000 \\
\hline & $\begin{array}{l}\text { [Teaching Method }= \\
\text { E Learning] }\end{array}$ & $\mathrm{Oa}$ & . & . & \\
\hline & IQ & 0.003 & 0.013 & 0.214 & 0.83 \\
\hline \multirow{4}{*}{$\begin{array}{l}\text { Quality of } \\
\text { achievements }\end{array}$} & Intercept & 3.739 & 0.089 & 42.22 & 0.000 \\
\hline & $\begin{array}{l}\text { [Teaching Method }= \\
\text { Traditional] }\end{array}$ & $-.424-$ & 0.055 & $-7.660-$ & 0.000 \\
\hline & $\begin{array}{l}\text { [Teaching Method }= \\
\text { E Learning] }\end{array}$ & Oa & & & \\
\hline & IQ estimates & 0.005 & 0.008 & 0.659 & 0.51 \\
\hline \multirow{4}{*}{ Performance } & Intercept & $-1.255-$ & 0.136 & $-9.230-$ & $0.000 *$ \\
\hline & $\begin{array}{l}\text { [Teaching Method }= \\
\text { Traditional] }\end{array}$ & 0.064 & 0.085 & 0.751 & 0.453 \\
\hline & $\begin{array}{l}\text { [Teaching Method }= \\
\text { E Learning] }\end{array}$ & Oa & . & - & \\
\hline & IQ & 0.126 & 0.012 & 10.156 & 0.000 \\
\hline
\end{tabular}

The table (3) showed that the effect of the E-Learning teaching method on the customers' satisfaction is higher than that of the traditional teaching method and the difference is statistically significant. Accordingly, these results supported the first hypothesis. Furthermore, the effect of the ELearning teaching method on the quality of achievements was higher than that of the effect of the traditional teaching method and the difference is statistically significant. Accordingly, these results supported the second research hypothesis. Regarding the effect of the E-Learning teaching method on students' performance, the results showed that there is not any difference. Accordingly, the third hypothesis is not supported. Both (MANCOVA) and (SEM) analysis reached the same results where the first and second hypotheses were confirmed while the third was not supported. These results are also shown in figure (2).

To examine the fit of the model to the data, Structure Equation Model was used. The quality criteria of the study model according to the results of this analysis is shown in table (4).

Table (4) The Quality Criteria for The Study Model

\begin{tabular}{|c|c|l|l|}
\hline Research Model Fit Summary & References \\
\hline Measurement & Value & $\begin{array}{l}\text { Optimal range } \\
\text { relative chi-square } \\
\text { ratio of approximately five or less, } \\
\text { ratios in the range of } 2 \text { to } 1 \text { or } 3 \text { to } \\
\text { 1 are indicative of an acceptable } \\
\text { fit between } \\
\text { the hypothetical model and the } \\
\text { sample data }\end{array}$ & $\begin{array}{l}\text { Wheaton et al. } \\
\text { (1977) } \\
\text { Carmines and } \\
\text { McIver, 1981, page } \\
80\end{array}$ \\
\hline GFI & .882 & $\begin{array}{l}\text { goodness of fit index } \\
\text { GFI is less than or equal to 1. } \\
\text { A value of 1 indicates a perfect fit }\end{array}$ & $\begin{array}{l}\text { Tanaka and Huba } \\
\text { (1985) }\end{array}$ \\
\hline CFI & .948 & $\begin{array}{l}\text { comparative fit index } \\
\text { CFI values close to 1 } \\
\text { indicate a very good fit }\end{array}$ & $\begin{array}{l}\text { McDonald and } \\
\text { Marsh (1990) }\end{array}$ \\
\hline RMSEA & .038 & $\begin{array}{l}\text { root mean square error of } \\
\text { approximation } \\
\text { exact fit with the RMSEA }=0.0 \\
\text { about OS or less would indicate a } \\
\text { close fit }\end{array}$ & $\begin{array}{l}\text { Tanaka and Huba } \\
\text { (1985) }\end{array}$ \\
\hline
\end{tabular}

Both (MANCOVA) and (SEM) analyzes reached the same results, where the first and second hypotheses were confirmed while the third was not supported.

The following figure (2) shows the study model, the significance of the relationships and the quality of the model. 
Figure (2): The study Model

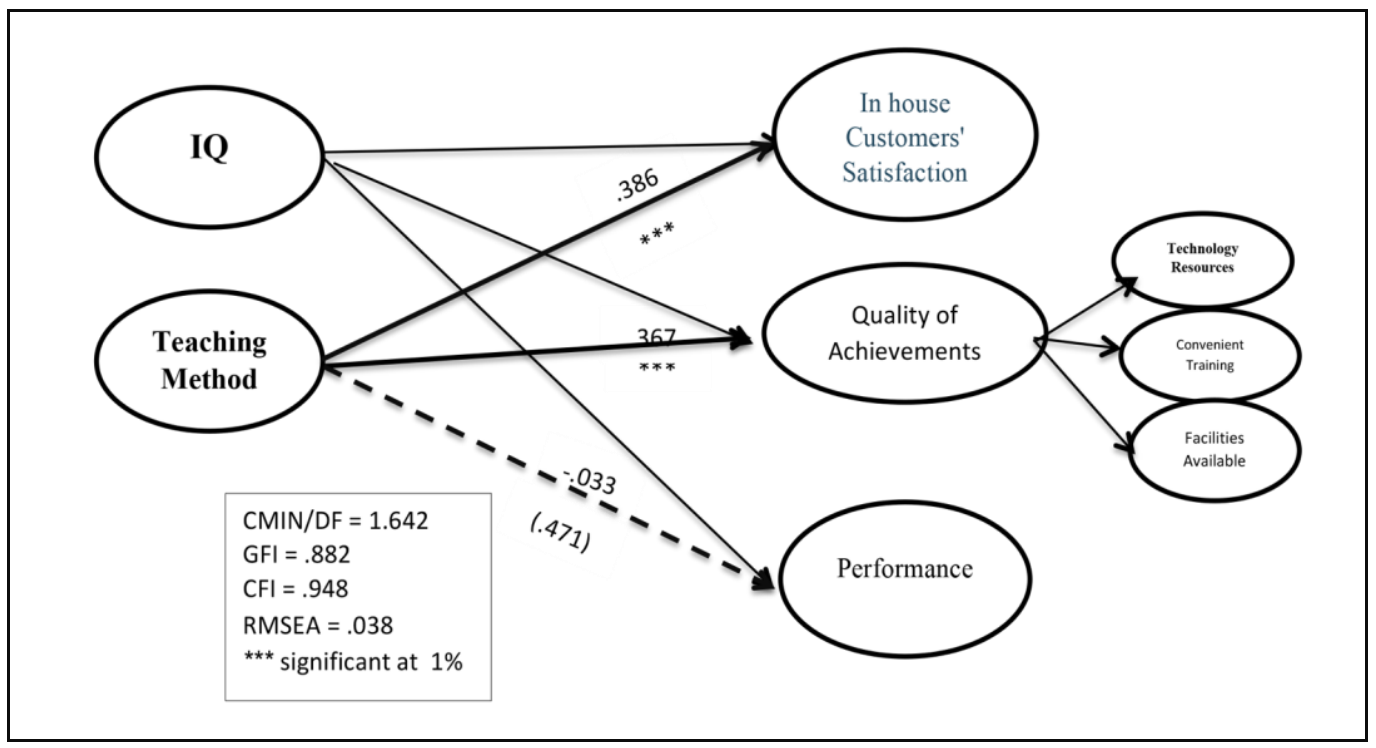

Discussions \& recommendations

Figure (2) shows the results of testing the fit of the model.

It is necessary to clarify the factors that affected the enhancement of the higher education at AASTMT. They should be used as guiding tools for the higher education in Egypt. The analysis tools were used in verifying the suitability of the design used for the data as well as achieving homogeneity among groups. For further verification of the results, the researcher did a double check for results by reexamining the model using the structure equation model (SEM) model. Both (MANCOVA) and (SEM) analysis agreed to accept and reject the same assumptions.

The study could generalize that E-Learning teaching method has a positive effect on in house customers' satisfaction and the quality of achievements. Although the students' performance for both teaching methods; being measured by exams, quizzes, assignments of end of tracks and GPA's of the learning outcomes; were equal, there is still different ways to measure performance and give the probability of significant results. Thus, the E-Learning teaching methods using technologies had its positive effects on students regarding such variables. The use of technologies brought several advantages to all students who were subjected to the E-Learning teaching method. AASTMT gave clear instructions to highly interact with students online. This interaction improved the performance of the E-Learning teaching method and this may be the reason for not having any significant difference among both teaching methods.

Recommendations: As the use of technologies brought several advantages regarding the students' satisfaction and quality of achievements, the lecturers should find ways to interact with students to make the students heavily participate in the process. The following concern should be highlighted that universities should revise their online measurements by focusing on the interaction between the professor and the students. Improvement of the E-Learning system used in different universities should be revised and re-assessed. Universities which did not successfully implement E-Learning should revise their strategies and their systems and carry on improving the E-Learning education process.

\section{Study limitations and suggested future research}

There is always a deep need for further research to comply with the effectiveness norms of using technologies and E-Learning applications. The following recommendations are to overcome limitations of the study and for future research:

The study was not generalized in public universities; it is required to have more results and directions towards the effect of E-Learning in enhancing education and improving quality in such universities. As the study was applied at AASTMT, The Arab Academy for Science, Technology and 
Maritime Transport is one of the Leagues of Arab States' specialized organizations in the fields of education, training, and consultancy, with a nature and culture completely different from public universities. The study could not be generalized on public universities without executing a similar study within to improve performance and sustain competitive advantages.

E-Learning represents organization complexity that needs deep studies. Therefore, studying large samples in several universities could lead to show more evidence in different universities and may widen the scope to be generalized in developing countries to enhance and improve higher education quality.

Studying more dependent variables too would widen the scope of the study, so as to analyze the effect of E-Learning teaching method versus traditional teaching method.

A proposed longitudinal study during two consecutive terms or more to follow up with students' performance in more depth. This longitudinal study would reveal more in-depth measures, more in-depth results, and better results and thoughts. Widening the scope of the research opens the door for more future alarming research and future research interests. It could undertake the education process reform to improve the effectiveness of the education system in higher academic institutions.

Finally, a future research for the impact of E-Learning on academic staff, collecting their perceptions would give a parallel investigation by analyzing preferred teaching methods in regard to the best academic performance, in addition to exploring additional cost effectiveness of the system from that perspective.

\section{References}

Aljawarneh, S; (2020) 'Reviewing \& Exploring innovative Ubiquitous Learning Tools in Higher Education'. Journal of Computing in Higher Education, (https://doi.org/10.1007/s12528-019-09207-0).

Alsabawy, A; et.al., (2011) 'Measuring E-Learning System success', AIS electronic library 2011.

Alsabawy, A; et.al., (2013) 'IT Infrastucture services as a Requirement for E-Learning System Success', Computers \& Education 69 (2013) 431-451.

Aly, M; Qasi, S; Pua, C (2018) “Assessing E-Learning System in Higher Education Institutes”, Interactive Technology \& Smart Education, 15 (1) 59-78.

Attia et., al, (2016); 'A Model for Assessing and Enhancing Efficiency of E-Learning Systems', International Journal of Computer Applications, 156 (6) 0975-8887.

Bali, S; Liu, M; (2018) ‘Students Perceptions Toward Online Learning and Face -to-Face Learning Courses'. Journal of Physics (MISEIC - IOP Conf. Series), 1108/1/012094.

Bernard, M, et.al., (2014). A meta-analysis of blended learning and technology use in higher education: from the general to the applied. Journal of Computing in Higher Education, 26(1), pp. 87-122.

Debattista, M; (2018) 'A Comprehensive Rubric for Instructional Design in E-Learning ', the International Journal Of nformation \& Learning Technology, 35 (2) 93-104.

Delone, W; McLean, E, (2003) 'The Delone and Mclean Model of Information System Success: A Ten-Year Update', Journal of Management Information Systems, 19 (4):9-30.

Elfaki, N; et.al., (2019) 'Impact of E-Learning vs Traditional Learning on Student's Performance and Attitude', International Journal of Medical Research \& Health Sciences, 8(10) 76-82.

Fischer, H; Heise, L; Heinz, M; Moebius, K; Koehler, T (2015) "How to Identify E-learning Trends in Academic Teaching, Methodological approaches and the analysis of the Scientific Discourses", Interactive Technology and Smart Education, 12 (1) 31-43.

Fortune, M; et.al., (2011) 'Students Perceptions of Online or Face to Face learning and social media in hospitality and tourism', Journal of Online Learning, 7 (1) :1-16.

González-Gómez, D., et.al., (2016) 'Performance and Perception in the Flipped Learning Model: An Initial Approach to Evaluate the Effectiveness of a New Teaching Methodology in a General Science Classroom'. Journal of Science and Education Technology, 25(3), pp. 450-459.

Hadullo, K; et.al., (2017) “A Model for Evaluating E-Learning Systems Quality in Higher Education in Developing Countires", International Journal of Education \& Development Using Information \& communication Technology (IJEDICT), 13 (2) 185-204.

Hair, J.F., Black, W.C., Babin, B.J. and Anderson, R.E. (2010) Multivariate Data Analysis. 7th Edition, Pearson, New York.

Hassanzdeh, A. et.al., (2012) 'A Model for Measuring E-Learning Systems Success in Universities', Expert Systems with Applications, 39 (12).

Hunt, A.-M., (2015) 'Blended Online Learning in Initial Teacher Education: A Professional Inquiry into Pre-service Teachers' Inquiry Projects'. Journal of Open, Flexible and Distance Learning, 19(2), pp. 48-60. 
Isik, A. (2009) Perceptions of Students and Teachers About the Use of E-Learning /Sharing Portal in Educational Activities, Unpublished Thesis in Computer Education Technology.

Jafar Jalali, M. et.al., (2018) Analytical Assessment Process of E-Learning Domain Research between 1980 and 2014 ', International Journal of Management in Education, 12 (1).

Kemp, N; \& Grieve, R., (2014) 'Face to Face or Face to Screen? Undergraduates' Opinions and Test Performance in Classroom vs. Online Learning', Educational Psychology, 5 (1-14).

King, E; Boyatt, R; (2014) 'Exploring Factors That Influence Adoption Of E-Learning Within Higher education', British Journal of Educational Technology, 46 (6) 1272-1280.

Kouhang, A; \& Durnte, A., (2003) 'Learners' perceptions Toward the Web Based Distance learning activities/assignments portion of an undergraduate hybrid Instructional model', Journal of Informational Technology Education, 5 (105-113).

Lara, J; et.al., (2020) 'special Issue on The Current Trends in E-Learning Assessment'. Journal of Computing in Higher Education. (https://doi.org/10.1007/s12528-019-09235-w).

Loh, C; et.al., (2016) 'Re-Examining Students' Perception of E-Learning: An Australian Perspective ', International Journal of Educational Management, 30 (1) 129-139.

MacDonald, C. J., Stodel, E., Farres, L., Breithaupt, K. \& Gabriel, M. A. 2001. The Demand Driven Learning Model: A framework for web-based learning. The Internet and Higher Education, 1(4): 9-30.

Macgregor, G; Turner, J; (2009) 'Revisiting E-Learning Effectiveness: Proposing a Conceptual Model', Interactive Technology and Smart Education, 6 (3) 156-172.

Mavondo, Tsarenko (2003) "Resources and Capabilities as Determinants of students Satisfaction”, Quality Assurance in Education Journal, 9(2), 1-10.

McDonald, R. P., \& Marsh, H. W. (1990). Choosing a multivariate model: Noncentrality and goodness of fit. Psychological Bulletin, 107(2), 247-255. https://doi.org/10.1037/0033-2909.107.2.247

Mwalumbwe, I; Mtebei, J; (2017) 'Using Learning Analytics to Predict Students' Performance in Moodle Learning Management System: Moodle Learning Management System'., The Electronic Journal of Information Systems in Developing Countries' (EJISDC), 79 (1) 1-13.

Nortvig, A; et.al., (2018) 'A Literature Review of The Factors Influencing E-Learning and Blended Learning in Relation to Learning Outcome, Student satisfaction and Engagement'. The Electronic Journal of E-Learning, 16 (1), pp. 46-55), available online at www.ejel.org.

Raspopovic, M; et.al., (2014) 'Success Factors for E- learning in a Developing Country: A Case Study of Serbia', International Review of Research in Open and Distance Learning, 15 (3) :1-23.

Ronald, A (2003) "A survey of Illinois Colleges to Identify the Administrative Issues to Be Considered when Delivering Online Instruction", Illinois College Publications.

Rowley, J (1996) “Measuring Quality in Higher Education”, Quality in Higher Education, 2 (3) 237-255.

Selim, H. (2007) 'E-Learning Critical Success Factors: An Exploratory Investigation of Students Perceptions', International Journal of Technology Marketing, 2 (2).

Sun, P; et.al., (2008)'What drives a successful E-Learning? An Empirical Investigation of the Critical Factors Influencing Learner Satisfaction', Computers \& Education, 50 (4) :1183-1202.

Tanaka, J. S., \& Huba, G. J. (1985). A fit index for covariance structure models under arbitrary GLS estimation. British Journal of Mathematical and Statistical Psychology, 38(2), 197-201

Tarus, J., K. (2015). Challenges of Implementing E-Learning in Kenya: A Case of Kenyan Public Universities.

Tratnik, A; (2017) 'Student Satisfaction with an Online and Face to Face Business English Course in a Higher Education Context', Journal Innovations in Education and Teaching International, 15 (1) 1-10.

Tsarenko, Y; et.al., (2011) 'International and Local Students Satisfaction': Resources and Capabilities Perspective", Journal.

Tseng, M; Lin, R; (2011) “Evaluating the Effectiveness of E-Learning System in Uncertainty”, Industrial Management and Data Systems, 111 (6) 869-889.

Vivek, A; Akash, A; Sucheta, A; (2016) “Assessment of Factors For E-Learning: An Empirical Investigation”, Industrial \& Commercial training, 48 (8) 409-416.

Wheaton, B., Muthen, B., Alwin, D., F., and Summers, G. (1977), "Assessing Reliability and Stability in Panel Models," Sociological Methodology, 8 (1), 84-136

Wright, C., (2014) 'Criteria for evaluating the quality of online courses'. Retrieved from https:/ / elearning.typepad.com/thelearnedman/ID/evaluatingcourses.pdf

Zare, M; et.al., (2016) 'The Impact of E-Learning on University Students' Academic Achievement and Creativity', Journal of Technical Education and \& Training (JTET), 8(1) 25-33. 